\title{
Effect of Market Capitalization on Economic Growth of East African Community
}

\author{
Ruth Kaiboi* $^{*} \quad$ Symon Kiprop Aquilars M. Kalio \\ School of Economics, Egerton University, P.o Box 536 - 20115, Egerton-Njoro, KENYA
}

\begin{abstract}
Stock markets in developing nations are faced with various constraints such as thin trading, liquidity issues and lack of developed investor base. Most stock markets in Africa are dominated by a single Industry as the backbone of the economy. Therefore, the main aim of this study was to establish effect of market capitalization on economic growth of east African community. The study was guided by Financial Intermediary theory. This study adopted causal research design. Data were obtained from: capital markets, Stock Exchanges (USE NSE, RSE and DSE) of the EAC member countries, annual Statistical report from the EAC website and World Bank as well. Analysis of the data was done using descriptive and inferential statistics. This study adopted a Panel Vector Autoregressive (Panel VAR) model. The results of this study indicated that stock market performance variables have a long run positive effect on the economic growth in the EAC and a bi-directional causality between market capitalization. Therefore, this research is beneficial to East Africa Securities Regulatory Authority (EASRA) in designing of policies that creates favorable business environment for stock markets to flourish. The study recommends that the EAC member governments should pursue policies that can contribute to increased liquidity as this would in turn lead to a higher stock turnover rate.
\end{abstract}

Keywords: Capitalization, Market, Economic Growth, East Africa Community.

DOI: $10.7176 / \mathrm{JESD} / 12-10-05$

Publication date:May $31^{\text {st }} 2021$

\section{Background of the study}

Financial systems play a critical role in contributing to efficient and a prosperous economic wellbeing of a country. It helps in mobilizing and pooling resources that are diverted towards gainful capital, stimulating economic growth. Alternately, economic growth assumes a critical part to guarantee that financial instruments are set up, prompting financial sector development (Levine, 2005).

Globally, financial markets comprise of bank-based systems and market-based systems. In market-based system securities shares takes the center stage with banks in getting societies savings to firms and managing risks. Market performance refers to a measure of stock market as an entirety or of a specific stock. It acts as a measure of economic performance in a manner which helps in distribution of the necessary capital required for the harmonization of growth in an economy (Osho, 2014). The shift in the price of a stock and the indexes portrays and hints on future trend of the stock, industry or the economy as a whole (Madaleno \& Pinho, 2012). The stock market's major role is to act as a financial institution. This improves the feasibility of capital formation and distribution, empower corporations and governments to expand long-lasting investment for financing new projects and inflate other operations (Shahbaz, Bhattacharya \& Mahalik, 2018).

African capital market is characterized by emerging and frontiers stock exchanges which are less efficient as compared to the developed market exchanges. Some of the most vibrant bourses are Johannesburg Securities Exchange (JSE), Nigeria Securities Exchange (NSE), Ghana Securities Exchange (GSE), Malawi Security Exchange (MSE) and Nairobi Security Exchanges (NSE), among other exchanges. All these exchanges have varied stock indices which are used to assess market performance.

East African Security markets have been facing numerous challenges in the last decade (2009-2019). These setbacks stem from political discontents and lack of robust development in the information exchange. These challenges are posing more glitches to the integration of the security markets in the EAC. In addition, there is a disparity in the depth of securities markets among the EAC member states (Ncube \& Mingiri, 2015). This is unlike the situation in many other blocs such as Southern African Development Community (SADC) and Middle East and North Africa (MENA). Among the EAC countries' where majority of the countries have similar dynamics in the stock markets as measured by market capitalization. Moreover, according to Allen et al., (2018) the East African security market are considered to have a low liquidity compared to other blocs because collectively their stock traded value is less than 1 percent of the value of their GDP.

Market capitalization is the total worth of a stock market. It represents the total market value of all the shares. Kenya has recorded better performance in terms of market capitalization. This is attributable to a relatively large number of listed firms in the Nairobi Securities Exchange. The market capitalization rate has fluctuated considerably between 2002 and 2015 after which it recorded a steady growth ending with 26,489 million Current USD in 2019. On the other hand, market capitalization in Dares Salaam Stock exchange has been recording highs and lows. The performance has been deteriorating since 2015 ending with a low of 10164 million USD in 2019. 
Uganda security exchange's market capitalization has had a steady flow between 2002 and 2015. It started showing a small decline and ended with 7804 million USD in 2019. Finally, Rwanda's stock exchange is the least performing among its EAC counterparts. It is however, worth noting that it has been on a growing trajectory and ended with 1 million USD in 2019.

\section{Statement of the Problem}

The East Africa community economies are at the initial stages of implementing short-term development goals and it is therefore important that the region strives to achieve a stable, competitive and sustainable middle-income economy. Economic growth is crucial in that it enables countries to improve the quality of living standards, creates employment and reduce debt to GDP ratio. A healthy economy encourages firms to take risks, innovates and invests in future products such as stock markets. However, East Africa community has continued to experience a sluggish economic growth where its GDP declined from 6.8\% in 2010 to 5.9 in 2019 (UNECA, 2019). If this trend continues to decline it may negatively affect the regions development goals of becoming a middle-income economy. Financial systems specifically the stock market promotes investment. The raising of capital allows companies to grow their businesses, expand operations and creates jobs in the economy.

Despite the fact that stock market performance in developing financial markets has the capability to enhance economic growth, its direct contribution to the combined economies of the countries in the EAC has not been adequately investigated. Several studies have attempted to establish a nexus between Stock market performance and economic growth. It is worth noting however, that majority of these studies have considered the relationship in a national setting (for example: Büyüksalvarci and Abdioglu (2010). Studies that have paid attention to trade blocs include a study by Nyanaro and Elly (2017), but this study, failed to establish a causal link between stock market performance and economic growth. The Study by Aduda, Masila and Onsongo, (2012) concentrated on GDP growth however, the current study focuses on GDP per capita as population is a critical factor in the analysis of Economic growth because it gives the true picture of the economy (Vossos, 2019). This study therefore was done with an aim to bridge existing gaps between effect of market capitalization on economic growth of East African Community.

\section{Theoretical Framework}

This study was guided by; Financial Intermediation Theory

\section{Financial Intermediation Theory}

Mitchell first developed Intermediary financial theory in 2004. The theory stresses the importance of having distinctive financial market members with other financial related data and how it adds to financial deepening, influencing financial development. The theory is fixed from asymmetry data and agency theory (DeMarzo, 2004). Asymmetry information theory centers around how financial business sectors are successful because of members having distinctive data concerning investment vehicles and dynamic. Subsequently making the financial market stability. The agency theory centers around the capacity of a monetary agent to deal with benefit of inventors' interest which is to make wealth and guarantee the economy stays stable.

Financial intermediation theory contains people or groups with different data, assets, and abilities to guarantee smooth progression of financial assets in the economy, bringing about economic advancement that decidedly influences the economy (Oldfield, 2010). The theory has been supported by Gorton and Pennacchi (2014), who demonstrated that financial intermediaries are mediators, yet they can likewise contain enormous foundations, for example, banks and other investment companies. As per the study, the accessibility of financial intermediaries has brought about the making of liquidity which is very critical towards financial development. For example, the presence of venture banks has guaranteed that monetary protections, for example, T-bills and corporate securities exchange effectively henceforth expanding investment the monetary financial markets. This theory however has a limitation in that it believes that intermediaries reduce transaction costs and information asymmetry, this may not be true all the time due to digital transformations

The intermediary financial model's commitment to this exploration is that it brings up the part played by money related go-betweens like banks, securities exchanges, and monetary foundations that go about as specialists to local area individuals and extension the liquidity gap. The financial intermediaries further assume a basic part in financial deepening through the dissemination of financial assets prompting financial development. In line with this study, monetary intermediaries could enhance market capitalization, which could go on to affect economic growth of East African community.

\section{Empirical Review}

\section{Market Capitalization on Economic Growth}

Biyan, (2012) conducted a study on the roles played by the stock exchange market on the Tanzanian economy. This study employed the case study based on triangulation and descriptive model in acquiring the needed 
qualitative and quantitative data. Furthermore, the outcomes established the obstacles that impede expansion of DSE to be; insufficiency of liquidity, low market capitalization, dilapidated macro-economic, high transaction costs, inadequate track - openness, unskilled human resources and inadequate public acknowledgement of DSE. These studies nevertheless paid attention to the role of stock exchange on economic expansion unlike this study which focuses on market capitalization on economic growth.

Study conducted by Obere et al., (2013) sought to establish the outcome of financial consolidation within the region and its impact on economic growth in EAC. Quantitative and qualitative data was obtained from the East African community between year 2000 and 2009 using general technique of moments. The results of the study established that regional financial integration greatly induced economic growth in the EAC. Unlike this study which focusses on effects of market capitalization, the study showed effects of financial integration on economic growth.

Aduda, Chogii and Murayi, (2014) conducted a study on the impact of capital market in relation to economic expansion in Kenya. Correlational research design was employed in establishing the influence of capital market widening variables on economic expansion. A multi variate model of regression was utilized to regress the independent variables against the dependent variable. The results of the study showed that 3 out of the 5 Capital Market dependent variables have a notable positive impact on GDP. Value Traded Ratio and Market Capitalization Ratio had remarkable negative correlation to the GDP growth. Nonetheless, the study showed much the effects of capital market deepening on economic growth in Kenya. Conclusively, there is need to examine the effects of market capitalization on economic growth across the East Africa countries.

Jalloh, (2016) did an assessment on the impact of stock market capitalization on economic growth and development in Africa, using dynamic panel. The findings showed that an increase in stock market capitalization by a marginal average of $10 \%$ stimulates an increase in growth by $5.4 \%$ going by the study. The findings also indicate that there is a positive and significant relationship between stock market capitalization and economic growth This study however paid attention on larger Africa unlike this study which focus on East Africa which is striving to achieve a common market and free trade ass.

According to a study done by (Nordin and Nordin, 2016) on the effect of capital market on economic expansion in Malaysia. The study used time series data and employed Johansen-Juselius co-integration test. The findings of the study reveal that there is a co-integrating link between capital market and economic growth and that stocks markets causes unidirectional cause and effect in the economy. The vector error correction model outlined both the stock market and the debt market has significant impact on Malaysian economy. This study however was conducted in Malaysia unlike the current study which focuses on East Africa countries. The markets in these countries are often affected by liquidity challenges. This could go on to affect the performance of markets in the region (Umuhoza, 2018; Chessar, 2015; Akileng et al., 2018).

\section{Conceptual Framework}

This study involved the use of GDP per capita as a dependent variable. Independent variables therefore included; market capitalization. The study used private investment and terms of trade as intervening variables.

Independent Variables

Dependent Variable

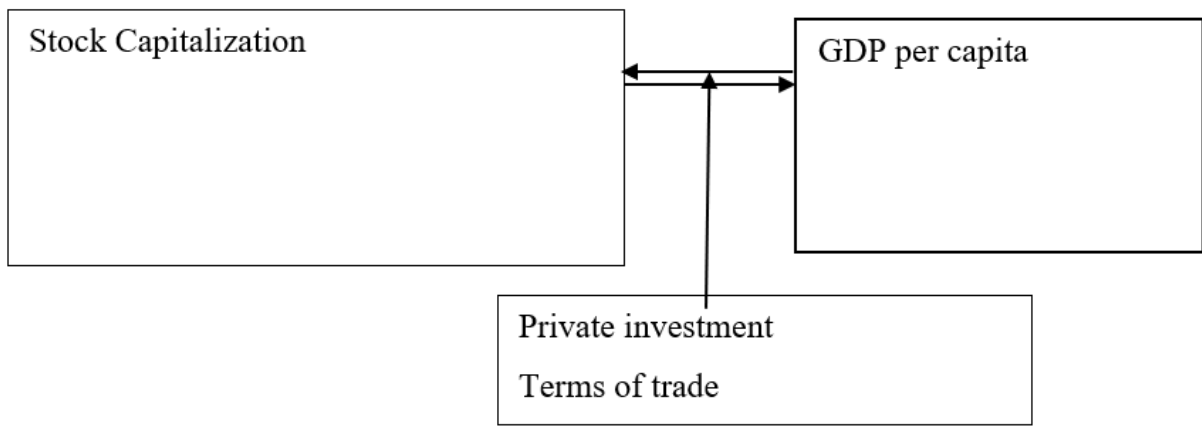

Control Variables

Figure 1: Conceptual Framework

\section{Research Methodology \\ Research Design}

The research design that was used in this study was Causal research design. According Kothari (2015) this design is considered useful in linking the dependent variable form the dependent variable with the aim of establishing the causal effect of the former on the latter. The design is also suitable for explaining trends and predicting future phenomenon. The choice of the design was informed by the data that was used in the study. The study used data 
that spanned for a period of 18 years, the data is considered sufficient to measure the trends and analyzing causality. The study also used a panel data approach in addressing the objective of the study that aimed to analyze the effect of stock market performance on economic growth in EAC.

\section{Market Capitalization}

Market capitalization, indicated by MC on the dependent variable, was measured through market value, market stock and market cap. The data was sourced from respective countries stock exchanges. Expected a positive sign. Market capitalization presents the investors with a hint of the size of the company and can even be utilized to contrast the size of different companies (Ray, 2012). The notion can also grant a presupposition about the future anticipations of individual companies since the market capitalization is an indicator of how much the public is prepared to pay for the stock of the company in question (Jaya \& Sundar, 2012).

\section{Data Collection and Analysis}

This study utilized secondary data collected from various sources such as; the capital markets, EASRA, the respective Stock Exchanges (USE NSE, RSE and DSE) of the EAC member countries and annual Statistical reports from the EAC website. Data for GDP per capita were collected from the World Bank database. The data collected in the study were analyzed using descriptive and inferential statistics with the aid of STATA. Descriptive statistics entailed Summary statistics and correlation analysis. Inferential statistic on the other hand included, regression analysis in this case the study adopted Panel Vector Autoregressive (Panel VAR) model as well as pre-estimation and post estimation diagnostic tests.

\section{RESEARCH FINDINGS AND DISCUSSIONS}

Summary statistics

Summary statistic is used to understand the behavior of the variables under study. Summary statistics forms the initial part of the study. It enables the researcher to understand the dataset in terms of normality and its fitness in empirical analysis. In this regard, descriptive analysis namely measures of central tendency and measures of dispersion were used in the analysis. The results are shown in Table 1 and it shows the mean, standard deviation, skewness and Kurtosis coefficients, it also displays results for the maximum and minimum figures.

Table 1 Summary Statistics of Variables

\begin{tabular}{llllllll}
\hline & N & Mean & Standard Deviation & Skewness & Kurtosis & Min & Max \\
\hline LogGDP & 72 & 8.8041 & 1.3512 & -.8469 & 2.3147 & 5.9810 & 10.2220 \\
LogMC & 72 & 22.2386 & 0.7512 & -0.2112 & 2.3958 & 20.7011 & 24.0857 \\
\hline
\end{tabular}

\section{Correlation Analysis}

This study uses Pearson's correlation analysis as the dataset exhibited normal distribution property as seen in Table 1 above. Correlation results are displayed in Table 2.

Table 2 Correlation Matrix for the Variables

\begin{tabular}{lll}
\hline & LogGDP & LogMC \\
\hline LogGDP & 1.0000 & \\
LogMC & $0.2642^{* *}$ & 1.0000 \\
& $(0.0249)$ & \\
\hline
\end{tabular}

** denote significant at 5\%

Table 2 shows the correlation matrix of the variables, as expected there is a positive and significant relationship between GDP per capita and stock market capitalization, however the relationship is weak as indicated by the coefficient of 0.2642 . Stock turnover ratio had a negative and significant relationship with GDP per capita, this relationship is weak as shown by the coefficient of -0.2193 . This result disagrees with economic theory as the two are expected to have a positive relationship. This could be explained by the declining trends in stock performance in EAC due to reduced investor confidence due to political tensions within the region in the past decade. Stock total value traded had a negative relationship with GDP per capita, however this relationship is weak as shown by the coefficient of -0.1118 , and insignificant.

On the control variables, Terms of Trade too had a negative association with GDP per capita, this association is weak and insignificant, and this violates economic theory. Investment has a positive and significant relationship with GDP per capita, as expected, with a correlation coefficient of 0.4084 .

\section{Panel Unit Root Tests}

In empirical studies, the use of non-stationarity time series data leads to spurious and inconsistent regression outcomes. To avoid these shortcomings, Im, Pesaran and Shin (2003) test was used to establish the presence or absence of unit root in the data. The IPS method was run on all the variables in levels and on first difference, the results are presented in Table 3. 
The test is based on the following hypothesis:

$\mathrm{H}_{0}$ : There is presence of unit root in each panel

$\mathrm{H}_{1}$ : There is absence of unit root in each panel

Table 3 Results for Im-Pesaran-shin (IPS) Panel Unit Root Test

\begin{tabular}{|c|c|c|c|c|c|c|}
\hline \multirow{2}{*}{\multicolumn{2}{|c|}{ Variable }} & \multicolumn{2}{|c|}{ IPS (Level) } & \multicolumn{2}{|c|}{ IPS (first Difference) } & \multirow{2}{*}{$\begin{array}{l}\text { Order } \\
\text { Integration }\end{array}$} \\
\hline & & Statistic & P-value & Statistic & P-value & \\
\hline \multirow[t]{3}{*}{ LogGDP } & t-bar & -1.3247 & & -7.0873 & & \\
\hline & t-tilde-bar & -1.2333 & 0.6465 & -3.0581 & 0.0000 & I (1) \\
\hline & z-t-tilde-bar & 0.3759 & & -4.4225 & & \\
\hline \multirow[t]{3}{*}{ LogMC } & t-bar & -1.4872 & & -4.1024 & & \\
\hline & t-tilde-bar & -1.4168 & 0.4580 & -2.8391 & 0.0001 & I (1) \\
\hline & z-t-tilde-bar & -0.1054 & & -3.8472 & & \\
\hline
\end{tabular}

Table 3 shows the panel unit root results. Apart from stock turnover ratio which is integrated of order zero, all the variables (GDP per capita, stock market capitalization.

\section{Panel Vector Auto Regression Model Estimation}

The model estimated a panel vector autoregressive (panel VAR). This technique was informed by some variables being non-stationary in level. Only stock turnover ratio was stationary in levels while the rest of the variables were stationary after the first difference. Secondly the choice of the models was informed by lack of co integration among the variables as established by the Westerlund panel co integration test. This means that overall combination of the variables was non-stationary.

Panel VAR was established by estimating three different models; each of the model contained each of the main variables namely market capitalization, stock turnover ratio and stock traded value. The first model was related to the first objective that aimed to investigate effect of market capitalization on economic growth of east African community.

This approach accounts for missing values within the dataset (especially after differencing some variables) by replacing them with zeros. The implication of this is that the results yield more consistent and efficient estimates. Panel data results are displayed in Table 4.

Table 4 Results from the Panel Vector Autoregression Analysis

\begin{tabular}{lc}
\hline Dependent variable (GDP per capita) & $\begin{array}{c}\text { Market Capitalization } \\
\text { (1) }\end{array}$ \\
\hline D_GDP & $0.4594 * * *$ \\
Standard error & $(0.112)$ \\
Z-Statistics & $(4.10)$ \\
\hline D_TOT & $0.2217 * * *$ \\
Standard error & $(0.0396)$ \\
Z-statistics & $(-5.60)$ \\
\hline D_INV & .0954714 \\
Standard error & $(0.0857)$ \\
Z-statistics & $(1.11)$ \\
\hline D_LogMC & $0.1263 * * *$ \\
Standard errors & $(0.0239)$ \\
Z-statistics & $(5.28)$ \\
\hline
\end{tabular}

\section{LogSTO}

Standard errors

Z-statistics

\section{LogTVL}

Standard errors

Z-statistics

Standard errors and Z-statistics in parentheses $* \mathrm{p}<0.1, * * \mathrm{p}<0.05, * * * \mathrm{p}<0.01$

Table 5 displays results of panel VAR analysis. The results show that stock market capitalization positively impacts economic growth in EAC. The first objective aimed to establish the effect of stock market capitalization on economic growth in EAC. These results are represented by the first model. The coefficient of stock market capitalization has its hypothesized sign (positive) and statistically significant at 5 percent level. This implies that a 1 percent increase in stock market capitalization leads to economic growth by 0.1263 percent. The study also rejects the null hypothesis that stated that stock market capitalization does not affect economic growth in EAC. The findings supported Nieuwerburg et al., (2006) who carried out a study to establish the effect of the Mauritius stock market on the economic growing. Using a time series data from 1989 to 2006, for market size, that is a 
turn lead to a higher stock turnover rate. This is justified by the connection between economic growth and stock market through increased liquidity as suggested by vast literature. This can be fulfilled by encouraging more companies to go public as this would increase liquidity in the stock market. Liquidity in the market has been shown to attract more foreign investment and portfolio that can spill over to the economy through human capital formation, innovation diffusion and increased investment opportunities.

\section{REFERENCE}

Aduda, J., Chogii, R. and Maina, T.M., 2013. Effect of Capital Market Deepening on Economic Growth in Kenya. Journal of Applied Finance and Banking, 4(1), 141.

Akileng, G., Ogwang, A.A. and Ssendyona, C., 2018. Determinants of performance of securities exchanges in East Africa. Journal of Finance and Investment Analysis, 7(3), pp.1-3.

Allen, F., Carletti, E. and Valenzuela, P., 2013. Financial intermediation, markets, and alternative financial sectors. Handbook of the Economics of Finance, 2, pp.759-798.

Biyan, K., 2012. The Role of Stock Exchange to the Economic Growth in Tanzania (Doctoral dissertation, The Open University of Tanzania).

Büyüksalvarci, A. and Abdioglu, H., 2010. The causal relationship between stock prices and macroeconomic variables: A case study for Turkey. Journal of Economic \& Management Perspectives, 4(4), p.601.

DeMarzo, P.M., 2005. The pooling and tranching of securities: A model of informed intermediation. The Review of Financial Studies, 18(1), pp.1-35.

Umuhoza Cyuzuzo, G., 2018. Factors influencing the development of capital market in Rwanda (Doctoral dissertation, University of Rwanda).

Gorton, G. and Pennacchi, G., 2014. Financial intermediaries and liquidity creation. The Journal of Finance, 45(1), pp.49-71.

Jalloh, M., 2016. Stock market capitalization and economic growth: empirical evidence from Africa. International Journal of Financial Markets and Derivatives, 5(1), pp.76-95.

King, R.G. and Levine, R., 1992. Financial indicators and growth in a cross section of countries (Vol. 819). World Bank Publications.

Madaleno, M. and Pinho, C., 2012. International stock market indices comovements: a new look. International Journal of Finance \& Economics, 17(1), pp.89-102.

Chessar, V., 2015. Effect of Firm's Market capitalization on stock market volatility of companies listed at the Nairobi securities Exchange. Retrieved from: business. uonbi. ac. ke.

Nordin, S. and Nordin, N., 2016. The impact of capital market on economic growth: a Malaysian outlook. International Journal of Economics and Financial Issues, 6(7S).

Nyanaro, E. and Elly, D., 2017. The Relationship between Stock Market Performance and Economic Growth in the East African Community. African Development Finance Journal (ADFJ), 1(1).

Obere, A., Muthoga, S., Mburu, K. and Muchai, D.M., 2013. Regional Financial integration and economic growth in the East African community.

Oldfield, G.S., 2000. Making markets for structured mortgage derivatives. Journal of Financial Economics, 57(3), pp.445-471.

Osho, A.E., 2014. The role of stock market on Nigeria's economic development. International Journal of Scientific and research publications, 4(4), pp.1-7.

Shahbaz, M., Bhattacharya, M. and Mahalik, M.K., 2018. Financial development, industrialization, the role of institutions and government: a comparative analysis between India and China. Applied Economics, 50(17), pp.1952-1977.

UNECA, 2018. Assessing Regional Integration in Africa IX: Innovation, Competitiveness and Regional Integration.

Vossos, M.K., 2019. The status quo of East African stock markets: Integration and volatility. African Journal of Business Management, 13(5), pp.176-187. 